Authors Pre-print (version submitted to Antiquity, prior to editorial review)

\title{
Against reactionary populism: Towards a new public archaeology
}

versión 1.0.0, revisión 1

May 20, 2017

Alfredo González-Ruibal, Pablo Alonso González \& Felipe Criado-Boado

*Institute of Heritage Sciences (Incipit), Spanish National Research Council (CSIC);

Avenida de Vigo s/n, 15705. Santiago de Compostela, Spain.

**Instituto de Productos Naturales y Agrobiología (IPNA), Spanish National Research Council (CSIC); Avenida Astrofisico Francisco Sánchez, 3, 38206 San Cristóbal de La Laguna, Spain.

**Author for correspondence; Email: pabloag10@hotmail.com

\section{Keywords}

Social Archaeology, Cultural Heritage, Populism, Neoliberalism, Multiculturalism

\section{Introduction}

From Brexit to Trump, 2016 has been a critical year in global politics. The panorama has changed so dramatically and so fast, that it will surely have a long-lasting impact in archaeology, anthropology and related fields. Heritage, ethics and the way we relate to the public will all be affected in one way or another. In fact, some shocked reactions by archaeologists and other social scientists (ranging from indignation to mea culpa) have already been aired in different media $^{1}$. In this article we reflect critically on the phenomenon of reactionary populism and how it affects the practice and theory of archaeology. By reactionary populism we understand a political form that is anti-liberal in terms of identity politics (multiculturalism, abortion, minority rights, religion, etc.) but ultimately liberal regarding economic policies. It is characterized by exacerbated nationalism, racism, xenophobia, the defence of male privilege, anti-elitism and anti-intellectualism (see critiques in Žižek 2006; Brass 2017). In the last instance, as Judith Butler states in a recent interview, it wants "to restore an earlier state of society, driven by nostalgia or a perceived loss of privilege" ${ }^{\prime 2}$. Our critique comes from our specific experience as social scientists living in Spain, a country where post-truth regimes and reactionary populism have not been the exception but the norm throughout most of the twentieth century-as in many others that have been subjected to dictatorial regimes: from Russia to Portugal. We use this experience to problematize commonly-held ideas about archaeology and heritage that have shaped the field during the last three decades. We argue that the liberal, multivocal model of the social sciences and the humanities is no longer a viable option and ask our colleagues to embrace an

\footnotetext{
1 http://www.anthropology-news.org/index.php/2016/11/22/archaeology-in-times-of-trump/

2 http://www.zeit.de/kultur/2016-10/judith-butler-donald-trump-populism-interview/seite-2
} 
archaeology that is ready to intervene in wider public debates not limited to issues of heritage matters or issues of local relevance, is not afraid of defending in the public arena the expert knowledge that it produces, and is committed to reflective, critical teaching.

On the $5^{\text {th }}$ of November 2016 the world was shocked: Donald Trump won the presidential election in the US. Actually, this was the second time the world received a political shock in just six months. The first surprise was the Brexit. For those of us who do not live in either the US or the UK, the result of the elections was perhaps not so unexpected. In Europe, Austria has been about to fall in the hands of a neofascist party; the Polish government has taken an authoritarian drift that has worried the European Union, but enjoys wide social support; Hungary is ruled by a democratically-elected extreme right-wing party embracing xenophobia and ultranationalism. These phenomena are in the rise in France, Germany, Denmark, Finland and the Netherlands. The situation is not too different in other latitudes: Colombians sent shockwaves through Latin America when they decided to vote "no" in a much awaited peace agreement to put an end to a war lasting 50 years and causing more than 200,000 casualties. In Brazil, people took to the streets to support a group of corrupt right-wing politicians in their endeavour to topple down a democratically-elected president with social leanings, Dilma Rousseff. So Mr. Trump is not an oddity. It is rather another symptom of our times. Unfortunately, democratic elections do not turn out as liberal academics would like them to.

What does all this have to do with archaeology? A lot. We argue that many social archaeologists (and cultural anthropologists) have promoted an agenda during the last decades, which have left us politically and theoretically disempowered. By social archaeology we understand all archaeologies concerned with the interface between the discipline and society, including community, public and indigenous archaeologies, and the so-called critical heritage studies (Merriman 2004; Smith and Wobst 2004; Harrison 2013). To be fair, the efforts to open up archaeology to society, to give voice to marginalized collectives, to foster participative practices, to reflect on the political implications of the discipline, to relinquish "authoritarian high modernism" (Scott 1998) in contexts where the epistemic authority of archaeologists has had terrible consequences for the people: this has all changed archaeology forever and for the better. The problem is that it is not enough.

\section{Are the People of Archaeology "The People"?}

It is not enough because The People is not just the people with whom archaeologists do community archaeology and who are usually identified with specific social groups, usually in a position of subalternity. In our rush to find subalterns to "emancipate", we have had little time to reflect on the subjects of social archaeology. Who is the public, who is indigenous, who is a subaltern are questions that have only been superficially addressed. All too often, archaeologists have contented themselves with romanticized and simplistic images of society, community and the People. Communities have been equated with specific kinds of subalternity in a "proletarian multiverse" defined by gender, ethnicity, race or sexual orientation, and described almost invariably in positive, almost epic, terms (Brass 2017). This had led to crude distinctions which have become hegemonic in social archaeology and critical heritage studies, namely, the duality between authorized and official versus non-authorized and informal heritage, or top-down versus bottom-up initiatives (Smith 2006). Authorized, top-down archaeology and heritage are described as authoritarian and conservative, their opposite as spontaneous and democratic. From this perspective, which maintains a traditional modern dualist oversimplification, archaeologists have been criticized for being supporters of authoritarian science and heritage. Thus, many practitioners have waved the flag of the People to avoid being cast in the mould of the reactionary scholar or insensitive heritage manager. 
Archaeologists are thus expected to be always with the People, understand their needs and advocate their Cause (Atalay et al. 2014). We want to give voice to everyone, and we believe that every man and woman, every community, can become an archaeologist and spontaneously reclaim her or his heritage. However, we should be wary of Gramsci's lessons. The Marxist philosopher eloquently explained how modern societies tend to present their hegemonic projects as bottom-up and as the result of social negotiation and consensus. Thus, we have helped communities throughout the world to understand and to "master" their own linear views of time and to have "a past"; we have taught them that their past belongs to them as heritage, that heritage is part of their identity with an intrinsic value, and, more recently, that the universality of heritage makes it a good touristic product. We have considered that heritage is universal and good and that the People have it spontaneously. We only have to help them out.

In sum, we have invented the People that we need. A People that might challenge monolithic perspectives of heritage and archaeology and may even ban access to this or that site or reclaim such and such artefacts, but that is pretty much all: we can still maintain our liberal discourse and much of our epistemic practices. We do not want a People that rejects or lacks a notion of heritage, is not interested in the past, questions democratic values or resists multiculturalism. As Žižek (2002: 542) perceptively wrote "We can go on making our small choices, 'reinventing ourselves', on condition that these choices do not disturb the social and ideological balance". In a recent paper, Severin Fowles (2016) criticized the neomaterial turn arguing that archaeologists have found in things the perfect subject: one that does not dissent, lacks a proper voice, and complies with the archaeologist's longing for empowering the subdued masses.

Fowles, however, overlooks the fact that some archaeologists are also quite comfortable working with The People under the (pre-Trump) hegemonic multicultural framework. At least with some of them: homeless, Afro-descendants, indigenous peoples, working classes, immigrants. They are perfect subjects also, because they match very well the ethical-political imagination of both the liberal and Marxist practitioner. However, many people that could be easily labelled subalterns (for being economically marginalized, for instance, or belonging to the working classes) or at least as members of The People, actually seem intent into disappointing archaeologists by behaving in the wrong way: being as greedy as the ideal capitalist, patriarchal, xenophobic, uninterested in the past, destructive of heritage, etc. Yet about these unruly subalterns we hear little.

At work here there is an idealization of community and heritage: capitalism, exploitation and predation are always seen as exterior to the People, who will challenge these external enemies when they gather together-but each community (homeless, Cherokee, African-American, LGBTQ, etc.) on its own. This fragmentation of struggles (each subaltern community with its micro-fight) often leads not to greater social cohesion and political awareness, as social archaeologists might think, but rather to a pervading spread of the scapegoat culture, so dear to reactionary populisms (Žižek 2006). Social networks and new media have further exacerbated this problem: as an experiment by The Washington Post proved during the American elections, new forms of communication, such as the Internet or cable TV, have not only increased the fragmentation of struggles, but also of worldviews. Thus, one can be as a member of a group (i.e. liberal, cosmopolitan, white, Western academics) totally unaware of what other groups (i.e. unemployed citizens of small US mid-West towns) think, consume as news and react to ${ }^{3}$. The prioritization of the community as both the analytical focus of research and the locus of activism is, in fact, politically problematic. Rose $(1999,188)$, for instance, has shown that the ethics and politics of "governing through community" rationalizes the community as the appropriate locus for tackling social problems such as welfare, architecture, police, psychology or crime, thus leading to a wicked confluence: the state retreats; local self-responsibility and autonomy

\footnotetext{
${ }^{3}$ http://graphics.wsj.com/blue-feed-red-feed/
} 
increases. This is very much in tune with the neoliberal politics of privatization and social atomization.

Communities-the units in which the People are decomposed-are diverse, fragmented and complex. Some are progressive, some are not; some are cohesive, others are ridden by internecine conflicts. As Gaston Gordillo $(2014,257)$ has noted, the disposition of many working people "are multifaceted and contextual, and cannot be neatly encapsulated within a 'counterhegemonic' collective positioning". However, archaeologists and heritage practitioners have often transferred the qualities of the critical, enlightened subaltern (such as politicized indigenous groups or class-conscious working classes) to every community with which they work and, in the last instance, to the People as a whole-and here we understand, though this is hardly stated in any work of social archaeology, that the People are the non-elites, so between $70 \%$ and $95 \%$ of the population of any country. To put it simply: everything that is bottom-up, situated and local is nice.

This is what we call, following Ramón Grosfoguel (2008), "epistemic populism", which means that everything that the People say is right because it is the People who say it. What makes a statement true is not the logical consistency of the statement, but who utters it. This obviously resonates with the notion of post-truth, which has become so popular after the 2016 debacle. Thus, Mr. Trump's rebuttal of the figures for Inauguration Day is true, not because it is an empirically-proved fact, but because Mr. Trump said so. Before the Trump Era, epistemic populism had become hegemonic in social archaeology and heritage studies (e.g. Waterton and Smith 2010; Graham and Schofield 2014; Atalay et al. 2014), to the point that it has become anathema to criticize it. Basically, because a critique to the paradigm is seen as a critique to the People and therefore, a critique to the metaphor archaeologists live by. The emerging awareness of the dangers of postfactualism is starting to challenge this comfortable but naive position.

What we argue here is that epistemic populism is not critical (González-Ruibal 2012). First, it misrepresents the complexity of the People, by being blind to every social group that does not tally well with our progressive values. Second, the continual use of the language of multivocality and multiculturalism shows an uncanny alignment with neoliberalism or what Nancy Fraser (January 2, 2017) has called "progressive neoliberalism" (that is, progressive politics reduced to political correctness). Our Latin American colleagues know this well: multicultural archaeology goes hand in hand with capitalist endeavours and the interests of the nation-state (Shepherd aand Haber, 2011). Multicultural archaeology endorses a form of ethical cosmopolitanism that tolerates difference, promotes alternative symbols and their public representations and "outreach", but silences narratives and practices that truly escape the neoliberal logic (Gnecco 2015). Another problem is that multivocal and multicultural archaeologies reconstruct the transcendental subject: the one who speaks is the one who matters. This leaves outside those who do not or cannot speak (Spivak 1988), while at the same time limits emancipatory politics to the right to narrate (Žižek 2004: 547-548). The US elections, however, have shaken the certainties of epistemic populism and its cheerful alliance with multiculturalism: without its ideological façade, the king is now naked.

\section{Three things we have learnt from Mr. Trump}

To see the king naked has an obvious pedagogic value. There are three main lessons that can be drawn from the US elections. First, we have learnt that mere and more liberalism is not enough to face the reactionary onslaught. Liberal (progressive) archaeology, anthropology and the humanities and social sciences more generally are defenceless against Mr. Trump, Brexit or ultra-nationalism. Liberal archaeology has been incorporating more subjects into the hegemonic 
project of global liberalism symbolically, that is, by allowing them to co-participate in the production, staging and consumption of cultural identities and heritage experiences. However, neoliberalism has failed to incorporate these same subjects to the material wealth capitalism promised, especially after the 2008 economic crisis: it has provided symbols, but no jobs. If archaeology emerged as a discipline of the bourgeoisie for the bourgeoisie with the Industrial Revolution in the nineteenth century (Trigger 1989), social archaeology and the heritage industry thrived in the context of the multicultural, liberal democracies of the last three decades.

However, we have transitioned from the proletariat to the precariat. The times of the superfluous individual have come, that is, an individual who is not even exploited but merely excluded from the system. Capitalism is a system based as much on exclusion as on symbolic subjection and material attachment. The problem is that the system is less and less capable of counting on subjects shaped by stable experiences of work, discipline, education and processes of valorization (Sennett 1998), which is the framework under which archaeology made sense. What do we have to offer, as archaeologists, to the denizens of the decaying towns of the US Midwest? or the impoverished, racially-segregated suburbs of European metropolises? Or even more, to the thousands of colleagues whose work can only be temporal, precarious, lowly paid and ultimately superfluous (McGuire 2008: 98-138; Cleary et al. 2014). Listening to more voices, allowing the subaltern to participate in our projects or revaluing local heritage will not stop the reactionary wave. The reactionary ideology of right-wing populism is based on a scapegoat culture predicated upon fear and hatred of the Other and it preys on communities ravaged by economic crisis and social disarray. Liberal archaeology, suffused with epistemic populism, does not provide us with the political or intellectual weapons necessary to face what is coming: the coalition of predatory capitalism and reactionary populism.

Another thing that we may learn from the current political situation is that archaeologists are perhaps not as fearsome agents of Empire as we thought, even if some of them have collaborated eagerly with it. In the commercial sector, some archaeologists wonder: what is it going to happen with Cultural Resource Management (CRM) if the ultraconservative right applies its policies? Something that may happen is that the US joins the club of Uruguay, Brazil, Peru, Greece or Spain, where the right and its lobbies have drastically undercut the requirements for conducting CRM. The material remains of the past, living traditions and the environment can often be destroyed with little or no expert consultation (of either external experts or local communities): quicker construction, mining, deforestation, etc., higher revenue. Despite what some argue (e.g., Hutchings and La Salle 2015), predatory capitalism does not really need archaeologists, simply because it does not need legitimizing narratives: that was the outdated project of nationalism. It only needs the likes of Mr. Trump (and his millions of voters), who are willing to lift all obstacles in its way.

But perhaps the most important thing that we have learnt is that there were other subalterns out there who were not self-assertive indigenous communities, liberal African-Americans, classconscious industrial workers or homeless interested in documenting their lives. These other subalterns are white trash and they claim to be The (long forsaken) People: a neo-Nazi journal stated, referring to Mr. Trump's victory, that "The Working Class Won the Election" ${ }^{4}$. Hey, wait! Were not these our People? Were not these the bottom-up producers of non-authorized heritage? If this is so, then something went terribly wrong and we have not seen it coming. Whether we like it or not, the truth is that part of Mr. Trump's constituency is made of low-class voters who felt betrayed by the (neo)liberal order-the same that kindly accedes to ethical cosmopolitanism, harmless cultural diversity, LGTB rights and even immigrant heritage (Fraser 2017), these are people who are poor, uneducated, long-term unemployed, often drug-addicts, whose only way of eking out a living is joining the army or getting subsidies, and who live in

\footnotetext{
${ }^{4}$ http://nationalvanguard.org/2016/11/the-working-class-won-the-election/
} 
depressed environments, without the help of the community ties and social identity that guarantee some measure of ontological security to other subalterns-i.e., they are the superfluous people (superfluous for capital).

We knew beforehand, of course, that bad subalterns did exist, but they were identified with sectors of the People gone rogue: the best example would be immigrants turned jihadists through experiences of social marginalization and racism. But now we have found that there were other rogue subalterns. And they are much more powerful politically (because they are many). They are as poor, disempowered and culturally disoriented as second-generation immigrants in a Belgian banlieu, but they are also white, xenophobic and racist. They are blatantly ignorant and they are angry. These subalterns are probably not so much interested in rewriting history. It is not an issue of representation and story-telling that is at stake-the kind of issue that archaeologists like so much (because they are good at it). It is political economy and a redefinition of class and identity that are at stake. Social archaeologists and heritage students, alas, have little to offer in this situation. They may perhaps document the relentless suppression of various forms of alterity, whose pace will increase in the following years, and compensate this destructive process through the form of symbolic restitution that cultural heritage provides, but this will just satisfy the cultural needs of the liberal and educated middle classes. They may also help out transforming into heritage those economic sectors that will be shattered by the advance of unbridled capitalism: as we know, whenever an economic activity disappears, a museum is open in its place to showcase that same activity. But this will hardly appease those losers of global capitalism who voted for Trump.

\section{Three things we can do}

The situation is not hopeless. There are things that we can do, but first we have to get rid of epistemic populism. We need to face social reality as it is: complex and often ugly. Complex in that communities are extremely diverse and not always progressive. We cannot divide society into the bad (the elite), the good (the little guys and the scholars who work with them) and the ugly (scholars and professionals at the service of hegemony). Sometimes the little guys, the wretched of the Earth, side with the bad. The forgotten twentieth century (Judt 2008) may provide some lessons: during the many conflicts of the twentieth century in Europe, the bloodiest confrontations involved the People against the People. Rural communities and lowclass urban neighbourhoods became battlefields and spaces of extermination. In our country, Spain, we endured a dictatorship that lasted 40 years and that enjoyed a large measure of social support based on a combination of terror and the mass production and dissemination of factoids: a post-truth regime avant la lettre. This social support is still very present, sometimes subconsciously. As our Latin American colleagues, we have a long experience of tiny communities that do not behave "properly", that do not vote "correctly" or defend the "correct" ideas. Perhaps for this reason we are not surprised for the election of Mr. Trump or Brexit. Perhaps for this reason some of us have never embraced eagerly so-called critical heritage studies and considered that epistemic populism is hardly the answer to address our problems. At the same time, we have avoided the easy way of entrenching ourselves in our academic ivory tower: we have tried to do a socially-engaged archaeology that does not have to resort to populism, either political or epistemic. And we believe that this model is more needed now than ever in the world.

Rejecting epistemic populism, of course, is not enough. We are not suggesting that we have to relapse into old-fashioned epistemic, academic authoritarianism and treat people as if they were minors who have to be reprimanded. We do not consider ourselves the vanguard of the revolution: this is not a role we have to occupy. Not just because this sort of political hubris is wrong, but also because it is useless-amateurs and pseudoarchaeologists, for instance, are 
often better than us at conveying and popularizing simple and often reactionary narratives about the past, true or not, and have more public authority than scholars. In the same way that Mr. Trump or the pro-Brexit campaigners were more effective delivering their message than their liberal opponents 5 . Archaeologists actually never had much authority in many places to start with, and our absence in the most relevant cultural and political arenas (where historians, anthropologists or sociologists are called to intervene) should be a matter of concern for the discipline (González-Ruibal 2013). Now our limited influence is probably dwindling even more, with the epistemic crisis brought about by the Internet: anybody can teach anything. What we need, then, is an archaeology that does three things.

First, we need an archaeology that provokes the People, instead of flattering them (Sloterdijk 2011); this means a discipline that tells things that are uncomfortable and even against the flow, that problematizes and complicates narratives, histories, identities. We need an archaeology involved in historical explanation and not just lively story-telling or hyper-specific archaeometric analyses. Telling uncomfortable truths to those who are already convinced and ready to listen (our usual audiences) is not enough: we need to engage those who are on the antipodes of (even) liberal thinking. We must abandon our comfort zones, be ready to walk on the wild side, get battered in dirty fights. Provocation and community-work may not be good partners, but then public archaeology should not be limited to community archaeology. Community engagement is still enormously important, but is not enough. The public is bigger than the community-we use "public" here not as a noun equivalent to "audience", but in another sense: "Of or concerning the people as whole" (OED). To serve the interest of "the people as a whole", archaeologists have to perform critical public interventions that go beyond the local sphere and create social links and support collective action (McGuire 2008: 39-46) without reifying closed communities and identities. In that, historians, philosophers and sociologists provide good role models: they have often played a crucial public role without being attached to a specific community. In fact, the effectiveness of their work lies precisely in their independence.

Second, we need an archaeology that teaches. We need a critical and transformative pedagogy that teaches about archaeology but also uses archaeology to teach (Bartoy 2012). This pedagogical archaeology, which learns in the process of teaching, converses with social movements, communities, and institutions but is not necessarily attached to specific localities. Teaching has lost prominence among social archaeologists lately and is absent from some manifestos (see various examples in Atalay et al. 2014). Collaboration with local communities, which is the current hegemonic model of our relationship with society, requires an equality between actors that is at odds with teaching, which presupposes a teacher and a pupil, a provider and a receiver of knowledge. Admittedly, teaching by archaeologists is totally out of place in many non-Western (indigenous) contexts, where archaeologists have indeed more to learn than to teach. But it is direly needed in many others.

Since the early 1980s, we have grown accustomed to deconstruct our truths, to criticize the Enlightenment, reason and of modernity. Yet relativizing objectivity and deconstructing disciplines are probably things that Mr. Trump and the post-truth regime would be ready to celebrate. We defend that we have to reconstruct a new objectivity, even if we know that this is impossible to attain (Criado-Boado 2000; 2001). This new and critical objectivity should be at the base of our teaching. If we relinquish teaching, if we only encourage others, we will become more and more useless as social scientists: we may end up as mere facilitators, social media managers or entertainers, while other will do our work in our place. And we might not like it.

We have to teach not because, as some argue (Holtorf 2007), we want everybody to see the world with the eyes of an archaeologist for our own egotistical sake. The perspective that sees

5 http://www.vox.com/policy-and-politics/2017/1/11/14238274/trumps-speaking-style-press-conference-linguistsexplain 
the interest of archaeology as pitted against the interest of common people has to be qualified if we want to reinstate teaching to the place it deserves. To understand and preserve the traces of the past is in the interest of society, even if it is not immediately obvious to everybody (as a local museum or a community project can be). The fact that is not immediately obvious is what makes teaching necessary in the first place. However, the idea is not to convince people that heritage is universal and good and everybody has it, as we have always done (both conservative practitioners and critical heritage researchers: what changes is what is considered heritage only).

Instead, we believe that archaeologists, as social scientists, have unique tools to understand the world critically. Against prejudice, racism and xenophobia, it is social critique that we need more urgently. We have relinquished our epistemic authority but it is not too late to regain it. This we can do not by waving our titles, but by reformulating the relationships and values that connect the discipline and the public to prove our worth: we should not rely on hierarchical authority or on positivistic scientific rhetoric solely, but on trust on the discipline and our role as social agents (Alonso González 2016), who produce knowledge that is not reducible to subjective interpretive practices (Criado-Boado 2001).

Bruno Latour can be useful here, when he tackles the question of how to construct nonpatronising authoritative scientific discourses in a context of public distrust. As with any other scientific discipline, the reinforcement of the epistemic authority of archaeology would require an "appeal to the institution of science, rather than science. It is a question of trust, not of certainty. Certainty is epistemological, the institution of science requires much more" (Latour 2013: 3). We will achieve the credibility, reputation and legitimacy that build trust by doing our best job as socially-committed archaeologists, not by flattering the masses or simply turning to our natural shelter in times of crisis: objects.

Third, we need an archaeology that escapes the 'heritage crusade'. Lowenthal (1996) developed this concept to illustrate the way in which heritage had shifted from being a preoccupation of some cultured elites, to become a major popular pursuit in recent decades. Enlisting ourselves in this crusade might lead us to consider, as a Spanish project has recently proposed, that putting Pokemons in museums and heritage sites is a good way to attract the public and legitimate our practice $^{6}$. Heritage evicts historicity to valorize the symbolic aspects of cultural processes. Seeing heritage as a social construction is a key move of critical heritage studies, but it leaves untouched the definition of the category of heritage, and the reasons for the need for the heritagization of things, people and cultural processes. The gist of the heritage crusade under capitalism is value, which is simultaneously symbolic and economic. However, cultural and economic aspects are usually regarded as separated: the former fall into the realm of ethics, while the latter are naturalized as part of the normal state of affairs. Social archaeologists and critical heritage scholars normally deal with cultural and ethical aspects (the Good), and criticize the commodification of heritage (the Bad). In accepting the separation between economy and culture, however, they fall prey to a specifically Western capitalist paradox described by Gilles Dauvé: "Equality of rights alongside social inequality".

Under increasing pressure of neoliberal mandates in institutions, archaeologists have recently started to think in ways to make archaeology 'useful'. This has been part of the general crisis of the humanities and their apparent lack of usability. This crisis only arrived after the natural sciences surrendered to State and company-sponsored demands for usefulness, productivity and applicability, which were fulfilled through the alliance of science, technology and industry that won the Second World War. Archaeology as a producer of knowledge about the past was not in the best position to meet such demands. A practical solution, however, came with the recasting of the discipline as a producer of heritage. But there is a problem here: as in the case

\footnotetext{
${ }^{6}$ http://www.elmundo.es/cataluna/2016/09/01/57c7f51f22601d9e6d8b45a1.html
} 
of CRM, the truth is that capital does not need us for producing heritage as a commodity. After all, archaeologists are not the best at producing economic value: others do this better than us: here is the reason for the economic crisis of commercial archaeology and its lack of capacity for creating new sustainable economic activities. Instead, consider the economically successful (and invented) sites of Puma Punku in Bolivia, the Pyramids of Güimar in the Canary Islands, or the historically-themed resorts of South Africa (Hall and Bombardella 2005), but also of the prevalence of pseudoarchaeological narratives in (real) and relevant sites such as Tiwanaku in Bolivia and the TV show Stone Me, a sort of Stone Age Big Brother. As producers of economic value through heritage, we are largely irrelevant to global capitalism; as producers of symbolic value through multivocality and multiculturalism, we are politically harmless. Thus, we need to start thinking not in heritage, but in anti-heritage strategies. In de-heritagization rather than in heritagization. This does not of course involve the destruction of heritage, but thinking of history and memory in ways that bypass the capitalist-modernist framework of heritage. This strategy could also be a way to revalue and recreate links with traditions and folk culture, a realm that has been abandoned by liberal-elitist approaches to heritage and that has helped to break ties with the people that feel attached to such cultural forms.

To conclude: we have to make archaeology political again. We must stop flirting with progressive neoliberalism and go beyond those issues of identity, ethics and narrative that have occupied the political imagination and practice of archaeology for three decades. We need to go back to the hard core of politics-radical dissent, conflict, inequality-and reconstruct archaeology as a public engaged practice to make it a truly critical voice in the global stage.

\section{References}

Alonso González, Pablo. 2016. Between Certainty and Trust: Boundary-Work and the Construction of Archaeological Epistemic Authority. Cultural Sociology 10 (4):483 - 501.

Atalay, S., Clauss, L. R., McGuire, R. H., \& Welch, J. R. (Eds.). 2014. Transforming archaeology: Activist practices and prospects. Walnut Creek, CA: LeftCoast.

Bartoy, K. M. 2012. Teaching through rather than about: Education in the context of public archaeology. In R. Skeates, C. McDavid \& J. Carman (eds.), The Oxford handbook of public archaeology, 552-565.

Brass, Tom. 2017. Who These Days is Not a Subaltern? The Populist Drift of Global Labor History. Science \& Society 81 (1):10-34.

Cleary, K., Frolík, J., Krekovič, E., Parga-Dans, E., \& Prokopiou, E. S. 2014. Responding to the Financial Crisis in Five European Countries: People, Roles, Reactions and Initiatives in Archaeology. Archaeologies, 10(3), 211-231.

Criado-Boado, Felipe, 2000. Walking about Lévi-Strauss. Contributions to an Archaeology of Thought, with a comment by J. Nordbladh and a response by F. Criado Boado. In C. Holtorf and J. Karlsson (ed.) Philosophy and archaeological practice. Perspectives for the 21th Century, pp. 277-303. Göteborg: Bricoleur Press.

Criado-Boado, Felipe, 2001. Problems, functions and conditions of archaeological knowledge. Journal of Social Archaeology 1(1): 126-146.

Dauvé, Gilles. 2009. Contribution à la critique de l'autonomie politique. Lettre de Troploin 9:145.

Fowles, Severin, 2016. The perfect subject. Journal of Material Culture 21(1): 9-27. 
Fraser, Nancy. 2017. The end of progressive neoliberalism. Dissent. January 2, 2017. Accessed January 23, 2017.

Gnecco, Cristóbal. 2015. "An Entanglement of Sorts: Archaeology, Ethics, Praxis, Multiculturalism." In Ethics and Archaeological Praxis, edited by Cristóbal Gnecco, 1-17. New York: Springer.

González-Ruibal, Alfredo, 2012. Against post-politics: a critical archaeology for the 21st century. Forum Kritische Archäologie 1: 157-166.

González-Ruibal, Alfredo (ed.), 2013. Reclaiming Archaeology: Beyond the Tropes of Modernity. London: Routledge.

Gordillo, Gastón. 2014. Rubble: The afterlife of destruction. Durham: Duke University Press.

Graham, B. and Schofield, John 2014. Who needs experts?: counter-mapping cultural heritage. Farnham: Ashgate.

Grosfoguel, Ramón. 2008. "Transmodernity, Border Thinking and Global Coloniality. Decolonizing Political Economy and Postcolonial Studies." Revista Crítica de Ciências Sociais 80:115-147.

Hall, Martin, and Pia Bombardella. 2005. Las Vegas in Africa. Journal of Social Archaeology 5 (1):5-24.

Harrison, Rodney, 2013. Heritage: critical approaches. London: Routledge.

Holtorf, Cornelius. 2007. Can you hear me at the back? Archaeology, communication and society. European Journal of Archaeology 10 (2-3):149-165.

Hutchings, Rich, and Marina La Salle. 2015. "Archaeology as Disaster Capitalism." International Journal of Historical Archaeology 19 (4):699-720.

Judt, Tony. 2008. Reappraisals: Reflections on the forgotten twentieth century: Random House.

Latour, Bruno. 2013. An inquiry into modes of existence: an anthropology of the moderns. Cambridge: Harvard University Press.

Lowenthal, David. 1996. Possessed by the past: the heritage crusade and the spoils of history. New York: Free Press.

McGuire, R. 2008. Archaeology as political action. Berkeley, CA: University of California Press.

Merriman, N. (Ed.). 2004. Public archaeology. London: Routledge.

Rose, Nikolas. 1999. Powers of freedom: Reframing political thought. Cambridge: Cambridge University Press.

Scott, James C. 1998. Seeing like a state: how certain schemes to improve the human condition have failed. New Haven: Yale University Press.

Sennett, Richard. 1998. The corrosion of character: the personal consequences of work in the new capitalism. New York: Norton.

Sloterdijk, Peter. 2011. Spheres, Volume 1: Bubbles: Microspherology. Los Angeles: Semiotext(e). Smith, Claire, \& Wobst, H. Martin. (Eds.). 2004. Indigenous archaeologies: decolonising theory and practice. London: Routledge.

Smith, Laurajane. 2006. Uses of heritage. London: Routledge.

Shepherd, Nick and Haber, Alejandro, 2011. What's up with WAC? Archaeology and 'engagement' in a globalized world. Public Archaeology 10(2): 96-115 
Spivak, Gayatri C. 1988. Can the subaltern speak? In P. Williams, L. Chrisman, (eds), Colonial and Postcolonial Theory. Basingstoke: McMillan, 271-313.

Trigger, Bruce G. 1989. A history of archaeological thought. Cambridge: Cambridge University Press.

Waterton, Emma \& Smith, Laurajane, 2010. The recognition and misrecognition of community heritage. International Journal of Heritage Studies 16(1-2): 4-15.

Žižek, Slavoj, 2002. A plea for Leninist intolerance. Critical Inquiry 28(2): 542-566.

Žižek, Slavoj, 2006. Against the populist temptation. Critical inquiry 32(3): 551-574. 